УДК 347.1

DOI: 10.54649/2077-9860-2020-3-53-56

\author{
Ж. Кайратұлы ${ }^{1}$ \\ ${ }^{1}$ Каспийский общественный университет, \\ Республика Казахстан, г.Алматы \\ E-mail: ali_2301@mail.ru

\section{ПРОБАЦИЯ КАК ФОРМА СОЦИАЛЬНО-ПРАВОВОГО КОНТРОЛЯ}

\begin{abstract}
Аннотация
Рассматривается пробация как форма социально-правового контроля лиц, освобожденных из мест лишения свободы, а также затронуты вопросы социальной адаптации и реабилитации названных лиц, с целью обеспечения общественной безопасности.

Ключевые слова: пробация, осужденные, условно осужденные, подозреваемый, обвиняемый, лишение свободы.
\end{abstract}

\author{
Ж. Қайратұлы ${ }^{1}$ \\ ${ }^{1}$ Каспий қоғамдық университеті, \\ Қазақстан Республикасы, Алматы қ. \\ E-mail: ali_2301@mail.ru
}

ПРОБАЦИЯ ӘЛЕУМЕТТІК-БАҚЫЛАУДЫҢ БІР НЫСАНЫ РЕТІНДЕ

\begin{abstract}
Аңдатпа
Пробация әлеуметтік-бақылаудың бір нысаны ретінде мақалада қылмыстық-атқару (пенитенциарлық) жүйесінің мекемесінен босатылған адамды әлеуметтік бейімдеу және оңалту арқылы қоғамның қауіпсіздігін қамтамасыз етуге жәрдемдесу мәселесі қарастырылған.

Түйінді сөздер: пробация, сотталғандар, шартты соттау, күдікті, айыпталушы, бас бостандығынан айыру
\end{abstract}

\author{
Zh. Kairatuly ${ }^{1}$ \\ ${ }^{1}$ Caspian Public University, \\ Republic of Kazakhstan, Almaty \\ E-mail: ali_2301@mail.ru
}

\title{
PROBATION AS A FORM OF SOCIAL AND LEGAL CONTROL
}

\section{Annotation}

Probation is considered as a form of social and legal control of persons released from places of deprivation of liberty, as well as issues of social adaptation and rehabilitation of these individuals, with the aim of ensuring public safety.

Keywords: probation, convicted, conditionally convicted, suspect, accused, imprisonment.

Республика Казахстан утверждает себя демократическим, светским, правовым и социальным государством, высшими ценностями которого являются человек, его жизнь, права и свободы [1]. Пробация - система видов деятельности и индивидуально определяемых мер контрольного и социально-правового характера, направленных на коррекцию по- 
ведения лиц, категории которых определены законом, для предупреждения совершения ими уголовных правонарушений [2].

Пробация основывается на принципах:

1) соблюдения прав, свобод и законных интересов человека и гражданина;

2) законности;

3) гуманизма;

4) гласности, за исключением сведений, составляющих государственные секреты и иную охраняемую законом тайну;

5) дифференцированного и индивидуального подхода при определении объема социально-правовой помощи и осуществлении пробационного контроля в отношении лиц, состоящих на учете службы пробации;

6) стимулирования правопослушного и активного общественно полезного поведения лиц, состоящих на учете службы пробации;

7) взаимодействия субъектов, осуществляющих пробацию.

Виды пробации

К видам пробации относятся:

1) досудебная пробация - деятельность и совокупность мер по оказанию социально-правовой помощи подозреваемому, обвиняемому, направленных на коррекцию их поведения;

2) приговорная пробация - деятельность и совокупность мер по установлению и осуществлению пробационного контроля в отношении лиц, осужденных к ограничению свободы, а также осужденных условно, и оказанию им социально-правовой помощи;

3) пенитенциарная пробация - деятельность и совокупность мер по ресоциализации лиц, отбывающих наказание в виде лишения свободы в учреждениях уголовно-исполнительной (пенитенциарной) системы;

4) постпенитенциарная пробация - деятельность и совокупность мер по установлению и осуществлению пробационного контроля в отношении лиц, освобожденных из учреждений уголовно-исполнительной (пенитенциарной) системы, и оказанию им социально-правовой помощи.

Пробационный контроль

1. Пробационный контроль осуществляется в отношении лиц:

1) осужденных к наказанию в виде ограничения свободы;

2) осужденных условно;

3) освобожденных условно-досрочно от отбывания наказания в виде лишения свободы.

2. Продолжительность пробационного контроля определяется приговором или постановлением суда.
Особенности осуществления пробационного контроля в отношении несовершеннолетних

1. Служба пробации осуществляет пробационный контроль в отношении несовершеннолетнего:

1) осужденного к наказанию в виде ограничения свободы;

2) осужденного условно.

Полиция осуществляет пробационный контроль в отношении несовершеннолетнего:

1) условно-досрочно освобожденного от отбывания наказания в виде лишения свободы;

2) в отношении которого судом назначена принудительная мера воспитательного воздействия, установленная пунктом 4) части первой статьи 84 Уголовного кодекса Республики Казахстан.

2. Служба пробации при постановке на учет несовершеннолетнего реализует комплекс мер в соответствии со статьями 69, 169 и 174 настоящего Кодекса в присутствии родителей или иных законных представителей, а при необходимости - педагога или психолога.

3. В отношении несовершеннолетних наряду с мерами, указанными в части второй настоящей статьи, служба пробации:

1) при задержании несовершеннолетнего, находящегося в розыске, незамедлительно вызывает родителей или иных законных представителей для опроса и установления причин и условий, способствовавших уклонению от отбывания наказаний;

2) совместно с представителями органа опеки и попечительства ежеквартально проводит обследование жилищных условий несовершеннолетних с составлением акта.

Условия пробационного контроля

1. Лицо, в отношении которого установлен пробационный контроль, вправе отказаться от получения социально-правовой и иной помощи. В таком случае отказ оформляется актом.

2. Лицо, в отношении которого установлен пробационный контроль, обязано:

1) явиться в течение десяти суток со дня вступления приговора или постановления суда в законную силу в службу пробации для постановки на учет;

2) соблюдать установленные настоящим Кодексом условия и порядок отбывания наказания и иных мер уголовно-правового воздействия;

3) являться в службу пробации для участия в профилактической беседе;

4) письменно информировать службу пробации об изменении места работы и (или) жительства.

3. Для достижения целей наказания и иных 
мер уголовно-правового воздействия служба пробации взаимодействует с государственными органами в соответствии с законодательством Республики Казахстан.

4. Местные исполнительные органы, общественные объединения и иные организации оказывают социально-правовую и иную помощь лицу, в отношении которого установлен пробационный контроль, в соответствии с индивидуальной программой, разработанной службой пробации.

Полномочия службы пробации

1) ведет учет лиц, в отношении которых установлен пробационный контроль;

2) разъясняет порядок исполнения возложенных судом обязанностей и привлечения к ответственности за их неисполнение;

3) разъясняет порядок и условия осуществления и прекращения пробационного контроля и привлечения к ответственности за нарушение порядка пробационного контроля;

4) разъясняет порядок предоставления и отказа от получения социально-правовой помощи;

5) устанавливает место жительства лица, состояние его здоровья, уровень образования и трудовую занятость, а также иные сведения, необходимые для определения объема предоставления ему социально-правовой помощи;

6) осуществляет иные функции, предусмотренные законодательством Республики Казахстан.

Последствия несоблюдения условий пробационного контроля, в случае несоблюдения лицом условий пробационного контроля служба пробации после письменного предупреждения направляет представление в суд [3].

По мнению, Г.Р. Рустемовой, в отношении которых, по мнению, применяется пробация. Права и обязанности лиц, состоящих на учете службы пробации. Категории лиц, в отношении которых применяется пробация, определяются уголовным и Уголовно-исполнительным кодексами Республики Казахстан [4, с. 117].

По мнению Р. Т. Нуртаева, меры социальной адаптации и реабилитации лиц, в отношении которых применяется пробация. Социальная адаптация и реабилитация лиц, в отношении которых применяется пробация: оказание социально-правовой помощи по вопросам:

- получение медицинской помощи;

- получение среднего образования;

- овладение профессией (профессиональная подготовка, переподготовка и повышение квалификации);

- содействие в трудоустройстве;
- обеспечение психологической поддержки;

- получение льгот и социальных выплат, установленных законодательством Республики Казахстан;

- социально-психологическое и психологическое консультирование;

- социальный патронаж;

- восстановление и формирование системы поддержки социальных связей, включающей содействие в восстановлении семейных и иных социально-позитивных связей в условиях взаимного согласия сторон • ;

- обеспечение места прибытия;

- организация реабилитационных мероприятий;

- привлечение к участию в культурных мероприятиях;

- социально-бытовая адаптация, включающая предоставление консультаций по социально-правовым вопросам [5, с. 47].

Пенитенциарная пробация применяется в отношении осужденного, отбывающего наказание в виде лишения свободы в учреждениях уголовно-исполнительной (пенитенциарной) системы.

Ресоциализация осужденного осуществляется с момента его прибытия в учреждение уголовно-исполнительной (пенитенциарной) системы в соответствии с требованиями уголовно-исполнительного законодательства Республики Казахстан.

В отношении осужденного, отбывающего наказание в виде лишения свободы, которому до отбытия срока наказания остался один год, ресоциализация осуществляется службой пробации совместно с администрацией учреждения уголовно-исполнительной (пенитенциарной) системы в форме оказания социальноправовой помощи.

Индивидуальная программа оказания социально-правовой помощи составляется и реализуется службой пробации совместно с администрацией учреждения уголовноисполнительной (пенитенциарной) системы.

Индивидуальная программа оказания социально-правовой помощи содержит:

1) данные досудебного доклада (при его наличии), разработанного службой пробации на этапе досудебной пробации;

2) материалы, характеризующие поведение осужденного в период пребывания в учреждении уголовно-исполнительной (пенитенциарной) системы;

3) сведения о возмещении и (или) невозмещении исковых требований лицом, подготавливаемым к освобождению; 
4) сведения о социальных связях осужденного, подготавливаемого к освобождению, состоянии его здоровья, уровне образования, трудовых навыках, осведомленности о правовых механизмах реализации прав и свобод, а также иные необходимые сведения для коррекции социального поведения и успешной социальной адаптации осужденного;

5) конкретные мероприятия, направленные на оказание социально-правовой помощи осужденному, подготавливаемому к освобождению;

6) планируемые мероприятия по оказанию социально-правовой помощи, трудовому и бытовому устройству осужденного после его освобождения.

Служба пробации совместно с администрацией учреждения уголовно-исполнительной (пенитенциарной) системы по просьбе лиц, подготавливаемых к освобождению, устанавливает их взаимодействие:

1) с центрами занятости населения для регистрации осужденного и предоставления ему информации о вакансиях;

2) со специализированными организациями (агентствами) по найму жилья;

3) с социальными службами для содействия пожилым лицам, инвалидам и лицам без определенного места жительства в получении социальных услуг.
При реализации индивидуальной программы оказания социально-правовой помощи служба пробации:

1) взаимодействует с иными субъектами, осуществляющими пробацию, по вопросам трудового и бытового устройства лиц, подготавливаемых к освобождению;

2) проводит работу по разъяснению лицам, в отношении которых применяется пробация, законодательства Республики Казахстан, регламентирующего порядок трудового и бытового устройства, информирует о действующих правовых механизмах реализации и защиты прав и свобод;

3) разъясняет объем и порядок получения социально-правовой помощи при освобождении из мест лишения свободы;

4) предварительно информирует о порядке осуществления административного надзора и пробационного контроля, а также последствиях его нарушения.

По словам Г. Л. Кригер, служба пробации осуществляет взаимодействие с государственными органами, гражданами, общественными объединениями и иными юридическими лицами по вопросам оказания социально-правовой помощи лицам, состоящим на учете службы пробации в соответствии с законодательством Республики Казахстан [6, ст. 47].

\section{Список использованных источников:}

1. Конституция Республики Казахстан (принята на республиканском референдуме 30 августа 1995 года) (с изменениями и дополнениями по состоянию на 10.03.2017г.)

2. Закон Республики Казахстан от 30 декабря 2016 № 38-VI «О пробации»

3. Уголовно-исполнительный кодекс Республики Казахстан от 5 июля 2014 года № 234-V (с изменениями и дополнениями по состоянию на 01.01.2018 г.)

4. Рустемова Г.Р. Проблемы борьбы с преступлениями в сфере медицинского обслуживания населения. - Алматы, 1999. - 296 с.

5. Нуртаев Р.Т. Қылмыс құрамы. - Алматы: ЖШС «Баспа», 2013. - 188 б.

6. Кригер Г.Л. Определение формы вины // Сов. юстиция. - 1999. - № 20. - С. 4-15.

\section{References:}

1. Konstitutsiya Respubliki Kazakhstan (prinyata na respublikanskom referendume 30 avgusta 1995 goda) (s izmeneniyami i dopolneniyami po sostoyaniyu na 10.03.2017 g.)

2. Zakon Respubliki Kazakhstan ot 30 dekabrya 2016 № 38-VI «O probatsii»

3. Ugolovno-ispolnitelny kodeks Respubliki Kazakhstan ot 5 iyulya 2014 goda № 234-V (s izmeneniyami i dopolneniyami po sostoyaniyu na 01.01.2018 g.)

4. Rustemova G.R. Problemy borby s prestupleniyami v sfere meditsinskogo obsluzhivaniya naseleniya. - Almaty, 1999. - $296 \mathrm{~s}$.

5. Nurtayev R.T. Kylmys құramy. - Almaty: ZhShS «Baspa», 2013. - 188 b.

6. Kriger G.L. Opredeleniye formy viny // Sov. yustitsiya. - 1999. - № 20. - S. 4-15. 